\title{
ADVOCATING GENDER AWARENESS AMONGST INDONESIAN MUSLIM WOMEN
}

\author{
Nabiela Naily \\ IAIN Sunan Ampel, Surabaya, Indonesia
}

Book Review

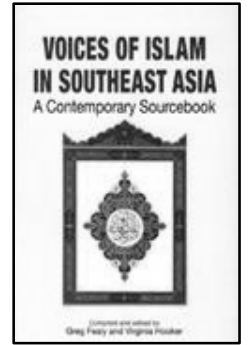

Book title : Voices of Islam in Southeast Asia; $A$ contemporary sourcebook.

Editors : Greg Fealy \& Virginia Hooker

No. of Pages : 540

Year : 2006

Publisher : The Institute of Southeast Asian Studies, Singapore

This book, Voices of Islam in Southeast Asia, compiles a significant amount of valuable data covering a wide array of important aspects regarding Muslim life in the region. The themes within the book are as follows: 'sharianh', 'Islam, state and governance', gender and the family', 'jiha», 'global and local; Muslims and non Muslims', and 'personal expressions of faith'. I shall focus on the fourth theme gender and the family (pp. 273-352).

Gender and women's issues in relation to Islam constitute one of the themes involving Islam most often questioned in western countries. Questions range from matters of personal expression, such as why Muslim women wear the veil, to more controversial issues like polygamy. One point worth attention is that many people in the West still believe that extreme acts, such as stoning to death, are common in Muslim countries like Indonesia. The chapter on gender and the family, in my view, foes a long way towards answering such questions. 
The section on gender and family is compiled by Sally White. She limits the case studies to two countries, Indonesia and Malaysia, reasoning that it is in these two countries that gender discourse has developed furthest. Moreover, the lack of sources regarding women's issues elsewhere forms an obstacle to including other countries in this research (p. 273). The author opens the theme by explaining why gender issues still matter; the fact that, in spite of their favorable position compared to women in Middle Eastern countries, "women in Southeast Asia still face many disadvantages vis-à-vis men".

The author's main argument is that the newly developing trends calling for gender equity and women's emancipation are countered by growing numbers of opponents, who question women's freedom and even want greater application of a purely scriptural interpretation of Islam in Indonesia. The author elaborates this argument by presenting various views regarding gender and women from sources representing diverse groups in Indonesia and Malaysia, ranging from educational institutions; pesantrens (traditional boarding schools which teach Islamic doctrines and teachings), Muslim organizations, prominent figures, academics and so forth. The chapter is divided into four sections beginning with the general topic and proceeding to more specific issues, namely: guides for creating the pious woman and the harmonious family, reinterpretations of Islamic texts emphasizing the equality between men and women, case studies on several issues, and legal challenges to prevailing Islamic law.

In the first section, the author summarizes conservative understandings towards the concept of piety for a Muslim woman, harmonious family and differences between men and women. The author points out that obedience to the husband after obedience to God is prescribed as the essential prerequisite for a woman to be considered pious. These views, are criticized as ambivalent. On the one hand, they claim that women's status is improved and that women are equal to men in front of the God according to Islam. On the other hand, they prescribe certain roles and types of behavior for women in the name of qudrah or fitrah (lit. predestined nature or character). Limitation is an unavoidable consequence of that.

In the second section the author goes on to offer a counterbalance. The more progressive views, she argues, have started to develop in countries like Indonesia and Malaysia, put forward by academic's namely Nasaruddin Umar and Musdah Mulia, or Muslim women's 
organizations such as Fatayat NU. The author argues that the common method used by this group is to reinterpret the texts beyond their literal meaning and emphasize the importance of universal values, justice and equality. To give an example, Nasaruddin Umar states as follows "If there is an interpretation that is not in accord with the principles of justice and human rights, then that interpretation must be reconsidered" (p. 290). The author admits, though, that these views cannot be considered as the attitude of the majority in Indonesia.

The lengthiest part of the chapter is the third section in which the discussion deepens to include several of the most debated issues in Indonesia and Malaysia, ranging from women's right to work, leadership in family, to even more sensitive issues like abortion and polygamy. Iin almost every issue, the pros and cons are presented. To give one illustration, after explaining FK3's opinions on the concept of family leadership, the author shows the FKIT's arguments in the opposing line. ${ }^{1}$ In this section readers can find a wealth of interesting information with regard to many controversial and practical gender issues, and from various points of view.

Realizing that the discussion would not be not comprehensive without covering the legal aspects of gender issues, the author closes her work with data on the relatively recent effort to reform the existing regulations regarding marriage for Muslims in Indonesia, KHI (compilation of Islamic family law) and the controversy it caused. In a chart, the author presents a comparison between the points of the existing KHI presidential instruction NO.1/1991 and its proposed changes called KHI counter legal draft (CLD). The controversy around this draft is illustrated in the debate between one of the drafters, Siti Musdah Mulia, and Chuzaemah Tahido Yanggo, a conservative professor on Islamic law and jurisprudence who is also co-writer of a book opposing CLD.

Voices of Islam in Southeast Asia, and this chapter in particular, is a valuable addition to scholarship on Islam and Muslims in Southeast

\footnotetext{
${ }^{1}$ FK3 (Forum Kajian Kitab Kuning) is a gender equity project discussing critical issues on women position in Islam as represented in medieval Islamic jurisprudences. FKIT (Forum Kajian Islam Traditional) is a forum with the mission to uphold the opinions of Muslim jurists as written in their books. Both FK3 and FKIT are within traditional stream of Nahdlatul Ulama.
} 
Asia. ${ }^{2}$ One of its major strengths is as a source-book, providing comprehensive introductory information regarding Islam and Muslims in the region. The lack of previous works which specifically focus on Islam in Southeast Asia gives makes the book's appearance even more significant. The choice of Southeast Asia itself is apt, since this region is, quoting Hefner in his commentary on this book, "one of the world's most populous and important centers of Muslim civilization, and yet is poorly understood..." Moreover, the editors have chosen the themes well, since these issues are arguably the most frequently asked about when Islam is discussed in the West.

Returning to the chapter on gender and the family, this section can be considered a first source, providing comprehensive discussion on gender issues in relation to Islam. Despite many studies on gender and women in Indonesia, works focusing on gender in relation to religion (here Islam) are few. Furthermore, those existing works tend to limit the scope to one organization, or one phenomenon, such as the work on Mulimat NU by Machrusah (2002). In contrast, in this work Sally White covers a wide variety of important aspects related to gender and Islam and arranges them in such a way as to help the reader navigate easily from the general topic to the most sensitive issues like polygamy and abortion. The author also includes some minor but important details such as the fact that many projects on gender discourse in these countries are funded by foreign donors, especially western governments or NGOs. Unfortunately, she fails to recognize that it is the fact that this support comes from abroad that raises suspicions among certain traditional Muslim communities towards ideas about gender, seeing see them as a 'western hidden agenda'.

On the whole, the aims of the book, and of this chapter, have been achieved. The book's principal aim is to provide an explanation of Islam in Southeast Asia, along with the diversity and the complexity of its ideas and practices, in order to correct people's impression of Islam in Southeast Asia being monolithic and similar to Islam in Middle East. In doing so, as far as the chapter on gender and the family goes, the author has presented various attitudes towards many issues, showed the pros and cons, and even painted a picture of some ambivalence in certain issues to emphasize that it is not as black and white as people

\footnotetext{
${ }^{2}$ It is unavoidable for me to also review the book as a whole in addition to reviewing the chapter on gender and women in particular.
} 
might think. In short, the author succeeds in illustrating the diversity and the complexity of gender discourse in Southeast Asia (represented by case studies; Indonesia and Malaysia).

Still, some issues need to be examined. One thing that captures my attention is the representation. Despite the author's efforts to include various viewpoints, some important representation is still not covered. One example: the poor representation of pesantrens. Arguing that Islamic educational institutions are important in developing ideas on women among Muslim community, the author makes the pesantren a data source. Unfortunately, only two pesantrens are researched: the "fundamentalist" pesantren of al Mukmin and the "modernist" Pesantren Gontor. Traditional Pesantrens from the NU (Nahdlatul Ulama) background are not represented, although the majority of pesantrens in Indonesia are from this stream, and most pesantrens in Indonesia are linked with NU. A brief explanation on the kitab 'Uqud, a commonly taught kitab in NU pesantrens concerning marriage, might be very helpful. The author also fails to consider the dynamics within organizations such as Fatayat NU. ${ }^{3}$ Whilst explaining Maria Ulfah's opinion on abortion, she forgets to state that this view might not represent the majority of Fatayat activist, especially those at the grassroots' level.

In addition to such limitations, I think this work could be more argumentative and critical with more analysis. Since only a few commentaries are available, this work is rather too descriptive and seems more like a compilation of information. As a result, the reader is left with inadequate conclusion. Putting the last section to close the chapter is not proper. As explained above, the last chapter is an autonomous section, explaining the legal reform effort in Indonesia. As such, it does not offer the readers any concluding point.

Nevertheless, this work is undoubtedly a much-needed contribution to the study of gender and women's issues in Indonesia. It provides a comprehensive explanation of Islam and Muslim life in Southeast Asia. The book can be easily understood by academics and non-academics alike. Students and analysts in the socio-political field will certainly benefit from its study Therefore, this source could be useful for both anyone who has an interest in understanding Islam in Southeast Asia in general, and gender issues in particular. []

${ }^{3}$ Fatayat NU is a female youth organization of Nahdlatul Ulama 